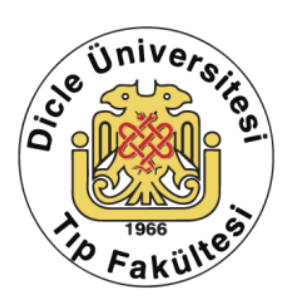

www.diclemedj.org

Özgün Araştırma / Original Article

\title{
Probable Interaction of MMP-2 and VEGF in Testicular Deteriorations Related to Aging
}

\author{
Servet Kizildag1, Ferda Hosgorler², Basar Koc ${ }^{3}$, Ozgur Golgelioglu4, \\ Guven Guvendi' ${ }^{5}$, Sevim Kandis ${ }^{6}$, Mehmet Ates ${ }^{7}$, Nazan Uysal ${ }^{8}$
}

1 College of Vocational School of Health Services, Dokuz Eylul University, Izmir, Turkey. ORCID: 0000-0003-3565-279X

2 Department of Physiology, Dokuz Eylul University, School of Medicine, Izmir, Turkey. ORCID: 0000-0001-6846-5312

3 Department of Physiology, Dokuz Eylul University, School of Medicine, Izmir, Turkey. ORCID: 0000-0003-2621-1693

4 Rame Health Products, Izmir, Turkey. ORCID: 0000-0002-0875-9607

5 Department of Physiology, Dokuz Eylul University, School of Medicine, Izmir, Turkey. ORCID: 0000-0002-1858-162X

6 Department of Physiology, Dokuz Eylul University, School of Medicine, Izmir, Turkey. ORCID: 0000-0001-8992-7985

7 College of Vocational School of Health Services, Dokuz Eylul University, Izmir, Turkey. ORCID: 0000-0002-8310-1979

8 Department of Physiology, Dokuz Eylul University, School of Medicine, Izmir, Turkey. ORCID: 0000-0002-2348-7427

Received: 17.06.2019; Revised: 01.11.2019; Accepted: 04.11.2019

\begin{abstract}
Objective: In the elderly, erectile dysfunction and hypogonadism have become more important due to the extension of human life. The most important morphological changes of the aged testis are associated with vascular deterioration, chronic hypoxia, fibrosis and hormonal changes. Vascular Endothelial Growth Factor (VEGF) and Matrix Metalloproteinase-2 (MMP-2) are directly related to these changes along with sperm motility and viability. The contribution of VEGF and MMP-2 to the structural and functional disturbances in the aged testis is unknown. The aim of this study was to determine VEGF and MMP-2 levels in the elderly testis and their interactions with one another.

Method: The testis tissues of aged rats (26-30 months) and adult rats (8-10 months) were analysed using the ELISA method to determine MMP-2 and VEGF levels. Serum total testosterone levels were analyzed using the immunoassay method. The statistical analysis was performed using the Mann Whitney-U test, $\mathrm{p}<0.05$ was considered significant. The results were presented with median and percentile values.
\end{abstract}

Results: In contrast to the adult testis, we observed that VEGF levels were increased [0.18(0.16-0.20) to $0.30(0.28$ $0.32)$ ] $\mathrm{g} / \mathrm{mg}$ respectively, $\mathrm{p}=0.009]$ and MMP-2 levels decreased [3.70 (2.07-4.74) to $1,10(1,08-1,29)$ ] $\mathrm{g} / \mathrm{mg}$ respectively, $\mathrm{p}=0.03$ ] in the aged testis. Serum total testosterone levels were lower in the aged group [5.45 (4.04-6.95) and 2.48 (1.93-3.11) $\mathrm{ng} / \mathrm{ml}, \mathrm{p}=0.004]$.

DOI: $10.5798 /$ dicletip

Yazışma Adresi / Correspondence: Ferda Hosgorler, Dokuz Eylul University, Medical Faculty, Physiology Dept. Balcova/Izmir, Turkey e-mail:ferda.hosgorler@deu.edu.tr 
Kizildag S., Hosgorler F., Koc B., Golgelioglu O., Guvendi G., Kandis S., Ates M., Uysal N.

Conclusion: Low levels of MMP-2 are consistent with deficiency of reproductive function but interestingly, VEGF levels were found to be high. MMPs have the potential to regulate the levels and activities of hormones. The absence of physiological effects of VEGF may be associated with MMP-2 deficiency. The therapeutic benefit of induction of MMP-2 activity in testicular hypogonadism is open to research.

Keywords: Aging, Hypogonadism, Matrix Metalloproteinase-2 (MMP-2), Vascular Endothelial Growth Factor (VEGF)

\section{Yaşlanmaya İlişkin Testiküler Bozulmalarda MMP-2 ve VEGF'nin Olası Etkileşimi}

\section{Öz}

Amaç: Yaşlılarda, erektil disfonksiyon ve hipogonadizm, insan yaşamının uzaması nedeniyle daha önemli hale gelmiștir. Vasküler bozukluklar, kronik hipoksi, fibrozis ve hormonal değişiklikler yaşlı testisinde oluşan morfolojik değişikliklere yol açar. Vasküler endotelyal büyüme faktörü (VEGF) ve matriks metalloproteinaz-2 (MMP-2) hem morfolojik değiş̧iklikler ile, hem de sperm hareketliliği ve canlılığı ile doğrudan ilişkilidir. VEGF ve MMP-2'nin yaşlı testisindeki yapısal ve fonksiyonel bozukluklara katkısı iyi bilinmemektedir. Bu çalışmanın amacı yaşlı testisinde VEGF ve MMP-2 düzeylerinin değişimini ve birbirleriyle etkileşimlerini belirlemektir.

Yöntemler: Yaşlı sıçanlarda (26-30 ay) ve erişkin sıçanlarda (8-10 ay) testis dokusundaki MMP-2 ve VEGF düzeyleri ELISA yöntemi ile analiz edildi. Serum total testosteron düzeyleri immunoassay yöntemi kullanılarak analiz edildi. İstatistiksel analiz Mann Whitney-U testi kullanılarak yapıldı, $\mathrm{p}<0,05$ anlamlı kabul edildi. Sonuçlar ortanca ve çeyreklik değerleri ile sunuldu.

Bulgular: Yaşlıların testislerinde erişkinlerin testislerine göre VEGF seviyelerinin arttığını [sırasıyla 0.30(0.28-0.32) ve $0.18(0.16-0.20)$ ] $\mathrm{g} / \mathrm{mg}, \mathrm{p}=0.009]$ ve MMP-2 seviyelerinin azaldığını [sırasıyla $1,10(1,08-1,29)$ ve 3.70 (2.07-4.74) ] $\mathrm{g} / \mathrm{mg}, \mathrm{p}=0.03$ ] bulduk. Serum total Testosteron düzeyleri yaşlı grupta daha düşüktü [5.45(4.04-6.95) ve 2.48 (1.933.11) $\mathrm{ng} / \mathrm{ml}, \mathrm{p}=0.004]$.

Sonuçlar: Düşük MMP-2 seviyeleri üreme fonksiyonu eksikliği ile uyumludur, ancak ilginç bir şekilde VEGF seviyelerinin yüksek olduğu bulunmuştur. MMP'ler VEGF seviyelerini ve aktivitelerini düzenleme potansiyeline sahiptir. VEGF'nin olumlu etkilerinin ortaya çıkmaması MMP-2 eksikliği ile ilişkili olabilir. MMP-2 aktivitesinin indüklenmesinin hipogonadizmdeki terapötik yararı araştırmaya açıktır.

Anahtar kelimeler: Yaşlanma; Hipogonadizm; Matriks Metalloproteinaz-2 (MMP-2); Vasküler Endotelyal Büyüme Faktörü (VEGF).

\section{INTRODUCTION}

Vascular aging, which is comprised of the structural alterations of the vessel wall and a functional insufficiency of the vascular endothelium, plays a critical role in the development of infertility and sexual dysfunction in the elderly ${ }^{1}$. In order to stimulate endothelial regeneration in the penile vasculature, vascular endothelial growth factor (VEGF), which exhibits paracrine, mitogen, and angiogenic effects, and forms the capillary network, has been extensively researched but there are few studies on the effect of VEGF in testicular aging 2,3 .

One of the most prominent morphological changes of the aged testis is vascular degeneration. Atherosclerosis of the arterioles, the thickening of the vessel walls and occlusion of its lumens, decreased capillary density, and the degredation of the peritubular capillary network cause a significant decrease in blood flow in the testis ${ }^{4}$.

Diminished blood flow leads to oxygen deprivation and fibrosis and results in a vicious cycle $^{4,5}$. Hypoxia Inducible Factor-1? (HIF-1?) 
induces VEGF expression at the transcriptional level in hypoxic conditions ${ }^{6}$. In the elderly testis, there is no information about whether hypoxia stimulates VEGF induction. It was reported that VEGF may increase germ cell proliferation, sperm motility and decrease apoptosis ${ }^{7,8}$. However, these positive effects of hypoxia-inducible VEGF on reproductive cells do not occur in the elderly. On the contrary, they are infertile. The efficacy of VEGF in decreasing the reproductive ability associated with aging is still unclear.

In addition to vascular impairment, fibrotic alterations are important structural changes in testicular aging. MMPs, which are a prominent regulator in many biological processes (such as extracellular matrix degradation, tissue remodeling, angiogenesis, apoptosis, cell proliferation) play an important role in both the vascular and fibrotic changes which correspond to aging 9,10 . Research has demonstrated that, in association with MMP-2 expression, hypoxia induces MMP-2 expression from fibroblasts, and endothelial angiogenesis is enhanced ${ }^{11}$. MMP-2 which can be isolated from testis and epididymal fluid is a critical component for sperm maturation ${ }^{12}$. MMP-2 level is associated with sperm count and quality. Sperm viability decreased and DNA fragmentation increased when MMP-2 was observed at low levels ${ }^{13}$. MMP-2 seems to have an important function in the role management of structural testicular changes and the reproductive functions related to aging. Similar to VEGF, hypoxia-inducible MMP-2 may have positive effects on the elderly testis, but the expression in the aged testis is unknown.

The aim of this study is to determine how VEGF and MMP-2 expressions are influenced by the hormonal and structural changes related to aging. The modulation of MMP-2 and/or VEGF expressions may help hypogonadism due to aging.

\section{METHODS}

\section{Animals and Experimental Procedures}

Sprague Dawley outbred male rats (26-30 months of age and 8-10 months of age, weighing 250-350 g) were provided from Institutional-Experimental Animal Laboratory. All rats were housed at constant room temperature $\left(22 \pm 1^{\circ} \mathrm{C}\right)$ under a 12 -h light/12-h dark cycle and had access to food and water ad libitum. All the experimental procedures were approved by the Institutional Medicine Animal Care Committee (tissues were obtained from the study whose approval number was 5.4.2018: 40/2018) and all animal experiments were conducted in accordance with the policies of the 'Guide for the Care and Use of Laboratory Animals, Eighth Edition'.

Aged rats with a mean age of 28 months (n: 7) and adult rats with a mean age 9 months (n: 7) were sacrificed under $\mathrm{CO}_{2}$ inhalation anesthesia which had a rapid and short-term anesthetic effect ${ }^{14}$. The testes were removed and tissue samples containing tunica albuginea and seminiferous tubules were obtained for measurements.

\section{Biochemical Evaluation}

Frozen samples of testicular tissue were weighed and homogenized with steel beads using Biospec Mini-Beadbeater-16 (BioSpec Products Inc., USA) in 10 volumes of PBS, $\mathrm{pH}: 7.4$ and centrifuged at $5000 \mathrm{~g}$ for $15 \mathrm{~min}$ at $4^{\circ} \mathrm{C}$. The supernatants were used for all biochemical analyses.

Tissue ELISA measurements for MMP-2 and VEGF were performed according to the kit protocol. The rat specific MMP-2 kit (Catalog No E-EL-R0618, Elabscience®, USA; with assay sensitivity: $0.19 \mathrm{ng} / \mathrm{mL}$ and detection range $0.31 \sim 20 \mathrm{ng} / \mathrm{ml}$ ), rat specific VEGF kit (Catalog No EK0540, BOSTER Biological Technology, U.S.A.; assay sensitivity $<1 \mathrm{pg} / \mathrm{mL}$ and detection range $15.6-1000 \mathrm{pg} / \mathrm{mL}$ ) was implemented for measurements. All results were calculated 
according to $\mu \mathrm{g} / \mathrm{mg}$ protein per tissue. Protein analysis was conducted according to the manufacturer guide of the BCA protein Assay kit (Catalog Number 23227, PierceTM BCA Protein Assay Kit,USA). All results were calculated according to mg protein per tissue. Absorbency changes were measured using a microplate reader (ELx800, BioTek Instruments, Inc., Winooski, VT, USA) at 450 $\mathrm{nm}$ for ELISA kits and at $560 \mathrm{~nm}$ for the protein assay kit. Serum total testosterone levels were measured on the Beckman Coulter DXI 800 analyzer according to the original kit protocol based on the competitive binding principle (reference range: $1.75-7.81 \mathrm{ng} / \mathrm{ml}$ ).

\section{Statistical Analysis}

The median and percentile values (25-75\%) of the variables were calculated for each group. The statistical significance of the differences between the groups was analyzed by using the Mann-Whitney U test on SPSS 15.0 program. $p$ values $<0.05$ were considered statistically significant.

\section{RESULTS}

Compared to the adult group, MMP-2 levels were reduced in the testicular tissues of the aged group, as illustrated in Table and Figure 1 [3.70 (2.07-4.74) and 1,10 (1,08-1,29) $0 \mathrm{~g} / \mathrm{mg}$ respectively, $\mathrm{p}=0.03]$. Compared to the adult rats, testicular VEGF levels were higher in the aged rats, as shown in Table and Figure 2 [0.18 $(0.16-0.20)$ and $0.30 \quad(0.28-0.32) \quad 0 \mathrm{~g} / \mathrm{mg}$ respectively, $\mathrm{p}=0.009]$. Compared to the adult rats, total testosterone levels were found to be at lower levels in the aged rats as indicated in Table and Figure 3 [5.45 (4.04-6.95) and 2.48 (1.93-3.11) $\mathrm{ng} / \mathrm{ml}$ respectively, $\mathrm{p}=0.004]$.

\section{DISCUSSION}

Understanding gonadal deficiency in elderly men is critical because the population of elder people worldwide is increasing. Elder people want to improve the quality of life as much as possible and eliminate inabilities. The role of histologic and morphologic changes on the loss of gonadal function are evident. Vascular changes (such as atherosclerosis, capillary occlusion etc.) and increasing fibrosis results in the decreasing of blood supply to the germinal epithelium. Likewise, increasing fibrosis also leads to seminiferous tubular sclerosis followed by testicular atrophy ${ }^{15}$.

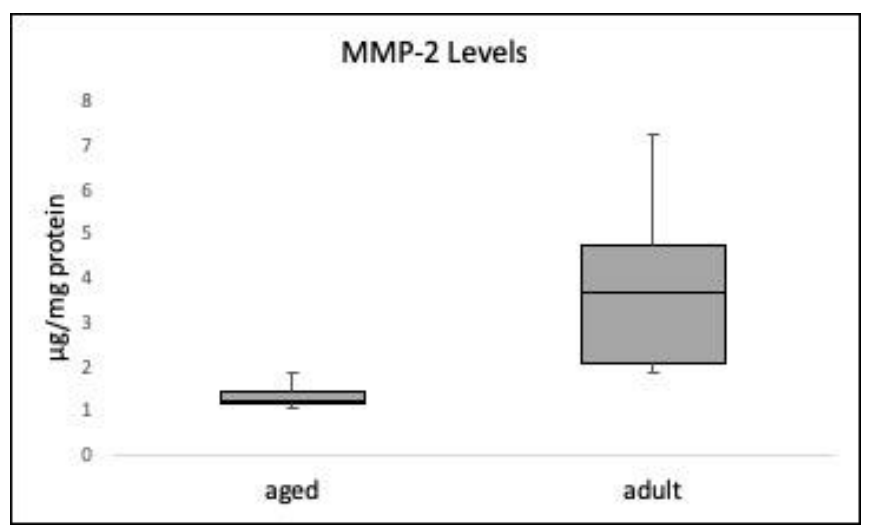

Figure 1. MMP-2 levels in adult and aged testicular tissues. MMP-2 levels significantly reduced in aged group compared with adult group $(\mathrm{p}<0,05)$.

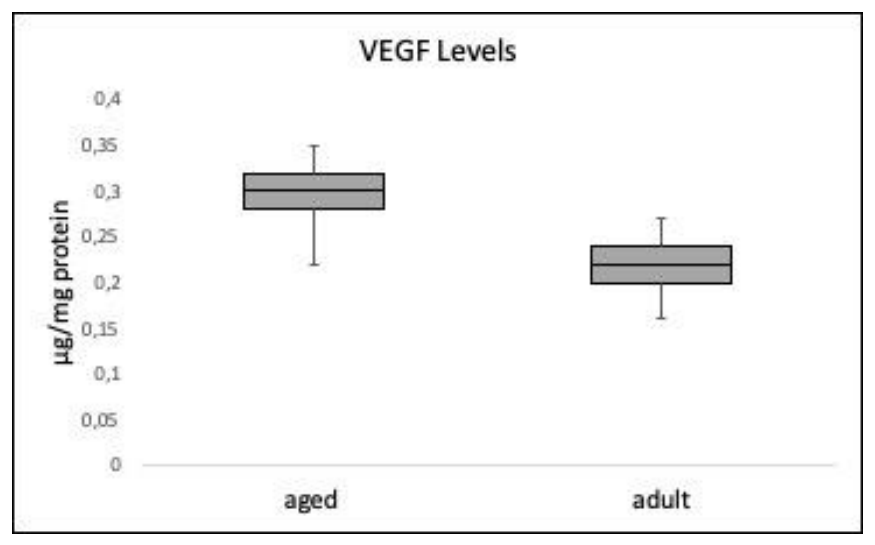

Figure 2. VEGF levels in adult and aged testicular tissues. In aged group VEGF levels significantly increased compared with adult group $(\mathrm{p}<0,05)$.

Research demonstrated that chronic hypoxia causes both fibrosis formation and decreases sperm count ${ }^{16}$. MMP- 2 and VEGF are important mediators of fibrosis, apoptosis, vascular regeneration and reproductive cells, which are all affected in the aging process. The relationship of these two major mediators, 
which play a role in testicular changes and reproductive abilities in old age, was not investigated.

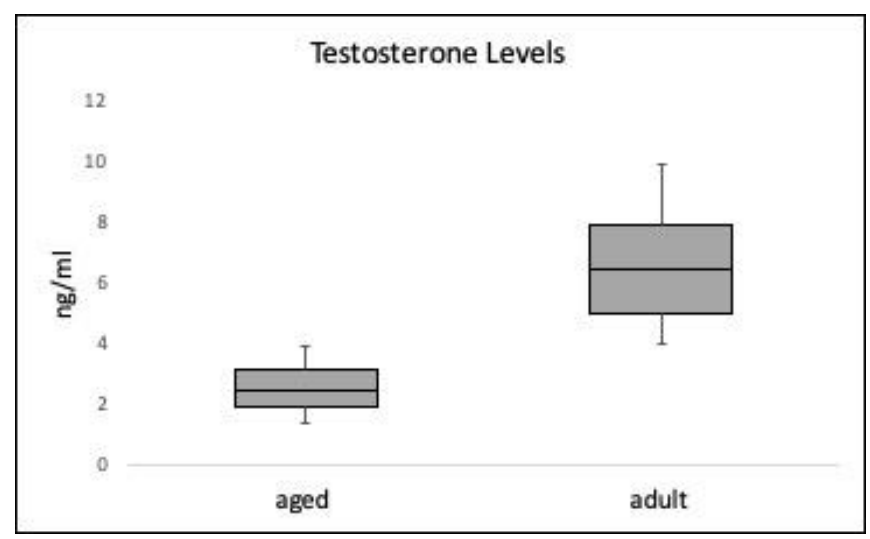

Figure 3. Testosterone levels in adult and aged testicular tissues. Testosterone levels were significantly lower in elderly rats than in adult rats.

In our study we detected that serum total testosterone levels and MMP-2 levels were diminished in the aged group. In old age, the circulating level of testosterone gradually decreases due to age-related hypofunctions of leyding cells and the slow production of hypothalamic gonadotropin-releasing hormone ${ }^{17}$. It was reported that testosterone and MMP-2 levels exhibit parallel changes in the elderly ${ }^{18}$. A study with aged rat cardiac fibroblasts demonstrated that testosteronetreated cells showed less collagen production and lower proliferation than those without testosterone and their MMP-2 production increased ${ }^{19}$. Testosterone administration to elderly rats decreased renal fibrosis and increased MMP-2 expression ${ }^{18}$. These findings were associated with weakened tumor growth factor $\beta 1$ (TGF- $\beta 1$ ) and downstream Smad 2/3 signaling, which triggers gene transcription of MMP-2 in the nucleus. It can be claimed that MMP-2 expression was suppressed in the TGF$\beta$ and Smad pathway in our elderly groups. On the other hand, this inhibitor pathway was eliminated in the adult group due to testosterone effect. MMP-2 expression was also affected by oxygenation. Although hypoxia was reported to induce MMP-2 expression in fibroblasts, the opposite effect was recorded in endometrial stromal cells ${ }^{11,20}$. Although the effect of hypoxia on MMP-2 is controversial, our results support a negative regulation. In previous studies, MMP-2 activity was found to be low in semen samples which had high DNA fragmentation and low sperm count ${ }^{21}$. Our low MMP-2 activity in elderly samples seems to be consistent with these findings.

We observed increased VEGF levels in the elderly testis. Similarly, the increase of VEGF was reported in different studies in heart and retina tissues associated with aging 22,23 . Increased levels of VEGF may be associated with chronic hypoxia. Hypoxia was shown to induce VEGF and VEGF reseptors through HIF-1 ? at transcriptional level ${ }^{24}$. The hypoxia in the elderly testis which is a consequence of fibrosis and vascular occlusion may induce VEGF.

There are few studies on the interaction of MMP-2 and VEGF, which are closely related to aging-related changes. MMPs can play a regulatory role in the function of chemical mediators by enzymatically cleaving various peptides, receptors, cytokines and growth factors ${ }^{9}$. MMPs was also reported to have the ability to regulate the transcriptions of some proteins, including VEGF, by nuclear translocation $^{25}$. Proteolytic cleavage of long chain isoforms of VEGF and the release of extracellular matrix-bound factors through proteolytic degradation may augment their effectiveness and bioavailability ${ }^{26,27}$. MMP-2 may stimulate the enzymatic release of sequestered VEGF (no interaction with the environment ${ }^{28}$. In this case, the inability of MMP-2 to process VEGF, even though VEGF was present, may interfere or mask the potential efficacy of VEGF. In our study, the efficacy of high levels of VEGF in the elderly rats compared to the adult rats may be low. Although high VEGF levels are expected to have a positive effect in terms of angiogenesis, sperm count and quality, the opposite effect can 
be observed in the elderly testes. This condition may be indicative of the inefficacy of VEGF or a result of the negative impact of VEGF in angiogenesis, sperm amount and quality. It has been suggested that MMP-dependent proteolytic cleavage is required for appropriate vascularization and the physiological angiogenesis response of VEGF (endothelial cell migration and proliferation in neovascularization ${ }^{28}$. Increasing expression of VEGF resulted in pathological angiogenesis ${ }^{29}$. In pathological VEGF expressions (such as tumor growth and metastasis, macular degeneration, diabetic retinopathy, and inflammatory processes etc.) VEGF promotes the mobilization of inflammatory cells and induces the local inflammatory process ${ }^{30}$.

Despite the high VEGF levels in the elderly, vascular insufficiency, inadequate sperm count and sperm quality indicate the low or pathologic efficacy of VEGF. The ineffectiviness of VEGF on testicular aging seems to be related to MMP-2 deprivation. It may be useful to increase MMP-2 activity for the beneficial effects of VEGF in elderly hypogonadism such as neoangiogenesis, sperm supportive and antiapoptosis.

Funding Statement: This study was not financed by any institution.

Declaration of Conflicting Interests: The authors declare that they have no conflict of interest.

\section{REFERENCES}

1. Gokce MI, Yaman 0. Erectile dysfunction in the elderly male. Turk J Urol 2017; 43: 247-51.

2. Ryu J-K, Suh J-K. Regenerative technology for future therapy of erectile dysfunction. Transl Androl Urol 2012; 1: 173-80.

3. Ergun S, Kilic N, Fiedler W, et al. Vascular endothelial growth factor and its receptors in normal human testicular tissue. Mol Cell Endocrinol 1997; 131: 9-20.
4. Santiago J, Silva JV, Alves MG, et al. Testicular aging: an overview of ultrastructural, cellular and molecular alterations. J Gerontol A Biol Sci Med Sci 2019; 74: 86071.

5. Regadera J, Nistal M, Paniagua R. Testis, epididymis, and spermatic cord in elderly men. Correlation of angiographic and histologic studies with systemic arteriosclerosis. Arch Pathol Lab Med 1985; 109: 6637.

6. Guo H, Zhou H, Lu J, et al. Vascular endothelial growth factor: an attractive target in the treatment of hypoxic/ischemic brain injury. Neural Regen Res 2016; 11: 174-9.

7. Yan-Ping D, Xiao-Qin G, Xiao Ping M, et al. Effects of Chronic Exposure to Sodium Arsenite on Expressions of VEGF and VEGFR2 Proteins in the Epididymis of Rats. Biomed Res Int 2017; 2017: 2597256.

8. Tian R, Yang S, Zhu Y, et al. VEGF/VEGFR2 Signaling Regulates Germ Cell Proliferation in vitro and Promotes Mouse Testicular Regeneration in vivo. Cells Tissues Organs 2016; 201: 1-13.

9. Mittal R, Patel AP, Debs LH, et al. Intricate Functions of Matrix Metalloproteinases in Physiological and Pathological Conditions. J Cell Physiol 2016; 231: 2599621.

10. Donato Anthony J, Machin Daniel R, Lesniewski Lisa A. Mechanisms of Dysfunction in the Aging Vasculature and Role in Age-Related Disease. Circ Res 2018; 123: 825-48.

11. Liu Y, Zhang H, Yan L, et al. MMP-2 and MMP-9 contribute to the angiogenic effect produced by hypoxia/15-HETE in pulmonary endothelial cells. J Mol Cell Cardiol 2018; 121: 36-50.

12. Warinrak C, Wu JT, Hsu WL, et al. Expression of matrix metalloproteinases (MMP-2, MMP-9) and their inhibitors (TIMP-1, TIMP-2) in canine testis, epididymis and semen. Reprod Domest Anim 2015; 50: 48-57.

13. Belardin LB, Antoniassi MP, Camargo M, et al. Semen levels of matrix metalloproteinase (MMP) and tissue inhibitor of metalloproteinases (TIMP) protein families members in men with high and low sperm DNA fragmentation. Sci Rep 2019; 9: 10234.

14. Kohler I, Meier R, Busato A, et al. Is carbon dioxide (CO2) a useful short acting anaesthetic for small laboratory animals? Lab Anim 1999; 33: 155-61. 
15. Pop OT, Cotoi CG, Plesea IE, et al. Correlations between intralobular interstitial morphological changes and epithelial changes in ageing testis. Rom J Morphol Embryol 2011; 52: 339-47.

16. Lee HC, Tsai SJ. Endocrine targets of hypoxiainducible factors. J Endocrinol 2017; 234: R53-R65.

17. Basaria S. Reproductive aging in men. Endocrinol Metab Clin North Am 2013; 42: 255-70.

18. Zhang G, Kang Y, Zhou C, et al. Amelioratory Effects of Testosterone Propionate on Age-related Renal Fibrosis via Suppression of TGF-beta1/Smad Signaling and Activation of Nrf2-ARE Signaling. Sci Rep 2018; 8: 10726.

19. Chung CC, Hsu RC, Kao YH, et al. Androgen attenuates cardiac fibroblasts activations through modulations of transforming growth factor-beta and angiotensin II signaling. Int J Cardiol 2014; 176: 386-93.

20. Zhang J, Salamonsen LA. Expression of hypoxiainducible factors in human endometrium and suppression of matrix metalloproteinases under hypoxic conditions do not support a major role for hypoxia in regulating tissue breakdown at menstruation. Hum Reprod 2002; 17: 265-74.

21. Belardin LB, Antoniassi MP, Camargo M, et al. Semen levels of matrix metalloproteinase (MMP) and tissue inhibitor of metallorproteinases (TIMP) protein families members in men with high and low sperm DNA fragmentation. Sci Rep 2019; 9: 903.

22. Marneros AG. Effects of chronically increased VEGF-A on the aging heart. FASEB J 2018; 32: 1550-65.

23. Kozhevnikova OS, Fursova AZ, Markovets AM, et al. VEGF and PEDF levels in the rat retina: effects of aging and AMD-like retinopathy. Adv Gerontol 2018; 31: 33944.
24. Barratt SL, Blythe T, Ourradi K, et al. Effects of hypoxia and hyperoxia on the differential expression of VEGF-A isoforms and receptors in Idiopathic Pulmonary Fibrosis (IPF). Respir Res 2018; 19: 9.

25. Sounni NE, Roghi C, Chabottaux V, et al. Up-regulation of vascular endothelial growth factor-A by active membrane-type 1 matrix metalloproteinase through activation of Src-tyrosine kinases. J Biol Chem 2004; 279: 13564-13574.

26. Ferrara N. Binding to the extracellular matrix and proteolytic processing: two key mechanisms regulating vascular endothelial growth factor action. Mol Biol Cell 2010; 21: 687-90.

27. Lee S, Jilani SM, Nikolova GV, et al. Processing of VEGF-A by matrix metalloproteinases regulates bioavailability and vascular patterning in tumors. J Cell Biol 2005; 169: 681-91.

28. Ebrahem Q, Chaurasia SS, Vasanji A, et al. Cross-talk between vascular endothelial growth factor and matrix metalloproteinases in the induction of neovascularization in vivo. Am J Pathol 2010; 176: 496503.

29. Lee RJ, Springer ML, Blanco-Bose WE, et al. VEGF gene delivery to myocardium: deleterious effects of unregulated expression. Circulation 2000; 102: 898901.

30. Melincovici CS, Boşca AB, Şuşman S, et al. Vascular endothelial growth factor (VEGF) - key factor in normal and pathological angiogenesis. Rom J Morphol Embryol 2018; 59: 455-67. 